Phase-Locked Loops

Principles and Practice 
Other titles of related interest

W.A. Atherton, From Compass to Computer

B.W. Allen, Analogue Electronics for Higher Studies

M. Beasley, Reliability for Engineers

C.W. Davidson, Transmission Lines for Communications, second edition

J.D. Edwards, Electrical Machines and Drives

M.E. Goodge, Analog Electronics

B.A. Gregory, An Introduction to Electrical Instrumentation and Measurement Systems, second edition

$\mathrm{K}$. Jackson, C Programming for Electronic Engineers

Paul A. Lynn, An Introduction to the Analysis and Processing of Signals, third edition

R.J. Mitchell, Microprocessor Systems - An Introduction

Noel M. Morris, Electrical Circuit Analysis and Design

M.S. Nixon, Introductory Digital Design - A Programmable Approach

P. Silvester, Electric Circuits

L.A.A. Warnes, Electronic and Electrical Engineering - Principles and Practice

L.A.A. Warnes, Electronic Materials

B.W. Williams, Power Electronics - Devices, Drivers, Applications and Passive Components

\section{New Electronics Series}

Series Editor: Paul A. Lynn

G.J. Awcock and R. Thomas, Applied Image Processing

Rodney F.W. Coates, Underwater Acoustic Systems

M.D. Edwards, Automatic Logic Synthesis Techniques for Digital Systems

Peter J. Fish, Electronic Noise and Low Noise Design

W. Forsythe and R.M. Goodall, Digital Control

C.G. Guy, Data Communications for Engineers

Paul A. Lynn, Digital Signals, Processors and Noise

Paul A. Lynn, Radar Systems

R.C.V. Macario, Cellular Radio - Principles and Design

A.F. Murray and H.M. Reekie, Integrated Circuit Design

F.J. Owens, Signal Processing of Speech

Dennis N. Pim, Television and Teletext

M. Richharia, Satellite Communications Systems

P.R. Shepherd, Integrated Circuits - Design, Fabrication and Test

M.J.N. Sibley, Optical Communications, second edition

P.M. Taylor, Robotic Control

G.S. Virk, Digital Computer Control Systems

Allan Waters, Active Filter Design 


\title{
Phase-Locked Loops
}

\section{Principles and Practice}

\author{
Paul V. Brennan \\ Department of Electronic and Electrical Engineering \\ University College London
}

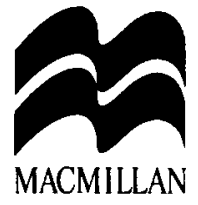




\section{2}

(c) Paul V. Brennan 1996

Softcover reprint of the hardcover 1st edition 1996 978-0-333-65571-9

All rights reserved. No reproduction, copy or transmission of this publication may be made without written permission.

No paragraph of this publication may be reproduced, copied or transmitted save with written permission or in accordance with the provisions of the Copyright, Designs and Patents Act 1988, or under the terms of any licence permitting limited copying issued by the Copyright Licensing Agency, 90 Tottenham Court Road, London W1P 9HE.

Any person who does any unauthorised act in relation to this publication may be liable to criminal prosecution and civil claims for damages.

First published 1996 by

MACMILLAN PRESS LTD

Houndmills, Basingstoke, Hampshire RG21 6XS

and London

Companies and representatives

throughout the world

ISBN 978-1-349-14008-4

ISBN 978-1-349-14006-0 (eBook)

DOI 10.1007/978-1-349-14006-0

A catalogue record for this book is available from the British Library.

$\begin{array}{rrrrrrrrrr}10 & 9 & 8 & 7 & 6 & 5 & 4 & 3 & 2 & 1 \\ 05 & 04 & 03 & 02 & 01 & 00 & 99 & 98 & 97 & 96\end{array}$


For my parents and for my wife, Francine 


\section{Contents}

$\begin{array}{ll}\text { Preface } & \text { ix }\end{array}$

1 Introduction 1

2 Loop Components 6

2.1 Phase detectors 6

2.2 Multiplier phase detectors $\quad 7$

$\begin{array}{ll}2.3 \text { Harmonic locking } & 12\end{array}$

2.4 Sequential phase detectors $\quad 15$

2.5 Frequency dividers $\quad 22$

2.6 Voltage-controlled oscillators (VCOs) 26

2.7 Loop filters 29

3 Loop Basics $\quad 31$

3.1 Design principles 31

3.2 Stability 33

3.3 Transient response $\quad 37$

3.4 Measurement techniques $\quad 43$

3.5 Phase-plane representation $\quad 47$

4 Modulation $\quad 58$

4.1 Single-point modulation $\quad 58$

4.2 Two-point modulation $\quad 66$

4.3 Demodulation $\quad 69$

5 Noise Performance $\quad 76$

5.1 Noise bandwidth $\quad 76$

$\begin{array}{ll}5.2 \text { Phase jitter } & 79\end{array}$

5.3 Effects of pre phase detector limiting $\quad 82$

6 Acquisition $\quad 90$

$\begin{array}{ll}\text { 6.1 Self-acquisition } & 90\end{array}$

6.2 Aided acquisition $\quad 94$

7 Higher Order Loop Filters $\quad 104$

7.1 Supplementary filtering $\quad 104$

7.2 The third order type II loop filter 106

7.3 Performance of the third order type II loop 109 
viii

8 Digital Loop Techniques and Design Methods 119

$\begin{array}{lr}\text { 8.1 Fractional-N synthesis } & 119\end{array}$

$\begin{array}{ll}8.2 \text { All-digital loops } & 127\end{array}$

8.3 Computer-aided design methods 135

9 Phase-Lock Applications $\quad 140$

$\begin{array}{ll}\text { 9.1 Frequency translation loops } & 140\end{array}$

$\begin{array}{ll}\text { 9.2 The Costas loop BPSK demodulator } & 144\end{array}$

$\begin{array}{ll}9.3 \text { A phased array controller } & 148\end{array}$

9.4 A PLL using an extended range phase detector 152

$\begin{array}{ll}9.5 \text { Lock-in detection } & 155\end{array}$

$\begin{array}{ll}9.6 \text { A bi-phase mark data decoder } & 160\end{array}$

$\begin{array}{lr}\text { Examples and Worked Solutions } & 164\end{array}$

Appendix A: Stability in Negative Feedback Loops 178

Appendix B: The Properties of Narrow-Band Phase Modulation $\quad 180$

Appendix C: The Equivalence of Frequency and Phase Modulation 182

Appendix D: Image-Rejection and Single-Sideband Mixers 185

Appendix E: Noise in Analogue Multipliers $\quad 188$

$\begin{array}{ll}\text { Appendix } F \text { : Intermodulation } & 194\end{array}$

Appendix G: Laplace Transforms 198

$\begin{array}{lr}\text { Glossary } & 199\end{array}$

$\begin{array}{ll}\text { Index } & 202\end{array}$ 


\section{Preface}

This book is intended as a concise guide to the theory and design of phase-locked loop (PLL) circuits. It is written from an engineering point of view, including numerous block diagrams, example circuits and experimental results, whilst making use of 'engineering' analytical methods such as signal flow graphs and Laplace transforms to retain a firm grip on the theoretical basis. Competent PLL design and analysis requires a considerable degree of theoretical understanding and yet it is a subject which is seldom formally taught to any depth. For this reason the book has a strong theoretical foundation, with most results derived from first principles, although mathematics is included for reasons of practical relevance rather than academic interest. This, hopefully, has resulted in a substantially self-contained text which should prove useful to both those new to and to those more familiar with the subject.

The initial motivation for the work came from a lecture course which I have been giving on PLLs since 1990 in the Department of Electronic and Electrical Engineering at University College London. This may explain the tutorial nature of parts of the book (such as the examples and worked solutions) which is slightly unusual in a PLL book and which should appeal to third/fourth year undergraduate and postgraduate students.

Although the book is relatively brief, a number of quite advanced analyses and sophisticated techniques are included, such as fractional- $N$ synthesis. I have endeavoured to treat the subject in a straightforward yet comprehensive fashion with the overall aim of providing a coherent, consistent reference which avoids cutting too many corners. A spin-off of this approach is that there are one or two techniques and treatments which I believe to be original to this text.

I would like to thank Brian Oughton for first introducing me to PLLs in 1984 and those who have since given me the opportunity of continuing my interest in this fascinating, elegant and very useful area of electronic circuits.

Paul V. Brennan 
Phase-Locked Loops

Principles and Practice 